\title{
Itinerario
}

http://journals.cambridge.org/lTI

Additional services for Itinerario:

Email alerts: $\underline{\text { Click here }}$

Subscriptions: Click here

Commercial reprints: $\underline{\text { Click here }}$

Terms of use : $\underline{\text { Click here }}$
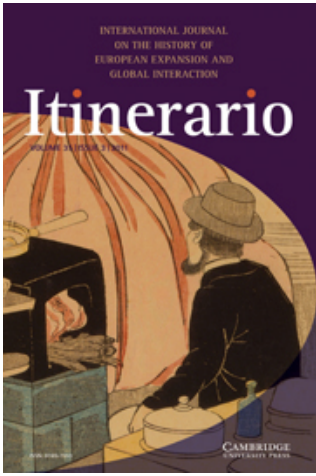

\section{Douglas R. Edgerton et al. The Atlantic World: A History, 1400-1888. Wheeling, IL: Harlan Davidson, 2007. 535 pp., 21 maps, 60 special topics with half- tones. ISBN: 9780882952451 (pbk.). $\mathbf{\$ 4 8 . 9 5 . ~}$}

Ronald Schultz

Itinerario / Volume 35 / Special Issue 03 / December 2011, pp 136 - 138

DOI: 10.1017/S0165115312000277, Published online: 14 March 2012

Link to this article: http://journals.cambridge.org/abstract S0165115312000277

How to cite this article:

Ronald Schultz (2011). Itinerario, 35, pp 136-138 doi:10.1017/S0165115312000277

Request Permissions : $\underline{\text { Click here }}$ 
lish Castorland and connect it to the rest of the country reveal the willingness of those two agents to work to overcome those transportation obstacles because they believed in a future of internal improvements.

Furthermore, Castorland Journal belongs within the project of Atlantic history that explores the various connections that developed among Europe, Africa, and the Americas over time. The publication contributes to this developing field by bringing to the attention of scholars a source that connects this international perspective to the study of a particular locality and region-upstate New York specifically and the Northern borderlands more generally. As Gallucci asserts in his introduction: "The story of Castorland is a story both regional and international" (xvii). Despite the persistent obsession with studying American national identity during the early Republic, the most important geographical category for understanding the Castorland settlement is not national. Indeed, with great bewilderment, Desjardins and Pharoux observed a significant number of Americans immigrating to Canada in the 1790s in search of inexpensive land. The French agents recognised the irony of Americans placing themselves under English "dominion" when they had previously fought a war "to shake off England's yoke." This occurrence is "Something for the preceptors of mankind to reflect upon!" the agents declare (21). Such Americans who immigrated to English Canada in the 1790s seemed willing to sacrifice national identity and republican values in pursuit of prosperity. This reminds historians that allegiance to the new American nation was not necessarily automatic for the entire population and that identities and loyalties remained fluid. Therefore, just as Atlantic history effectively counters American exceptionalist narratives of national development, the publication of Castorland Journal will help early Americanists to recognise the ways in which international and regional experiences combined to shape the ideological, social, and economic developments of the early Republic.

Although the Castorland experiment failed to attract a large number of settlers and supporters, the experiences of Desjardins, Pharoux, and others, as recounted in their journal, raise important questions about the role of upstate New York in the new American nation. Drawing attention to the significance of these Northern borderlands, the publication of this volume will enable historians to explore in greater detail the story of the Castorland settlement, the nature of French interest in the region, and why that settlement ultimately failed.

doi:10.1017/S0165115312000265

Michelle Orihel, Southern Utah University

Edgerton, Douglas R. et al. The Atlantic World: A History, 1400-1888. Wheeling, IL: Harlan Davidson, 2007. 535 pp., 21 maps, 60 special topics with half-tones. ISBN: 9780882952451 (pbk.). \$48.95.

During the mid-1990s a number of historians, many of them specialists in the history of colonial British America, began to expand the scope of American colonial history to include the Spanish colonisation of Mexico, Central America, and the Caribbean; the French commercial colonisation of Atlantic Canada and the eastern North American riverine systems; the Dutch colony on the Hudson; as well as the familiar British colonies from Maine to Georgia. As they joined this broader view to the work of social historians of the 1960s, 70s, and 80s, who had made Africans, American Indians, and women an integral part of the American colonial past, some of these historians began to develop a more expansive vision, not just of the colonial enterprise but of the colonial period as a whole. Out of this expansive vision developed the new field of Atlantic history. Between 1995 and 2005, publication lists exploded with articles and books taking an "Atlantic view" of conventional, and many not-so-conventional, topics. Among other things, The Atlantic World is a measure of what Atlantic history has accomplished.

The Atlantic World is a textbook first and foremost and it is designed to provide students 
in newly minted Atlantic history courses with the basic tools they need to understand the topic. But at the same time, the five authors go beyond textbook necessities to provide us with a comprehensive view of this new Atlantic world and the contribution Atlantic scholarship makes to our understanding of one important section of the early modern world.

The book begins with a discussion of the rationale for Atlantic history as a distinct field of study and argues for the unity of the four continents of Europe, Africa, and the two Americas and the ocean that connected them. Following that, the authors survey what they see as the most important developments on the four continents that led to their integration into a distinctively Atlantic world. The creation of that world is the subject of the next chapter, which details the formation of Iberian colonies and empires in the Americas between 1492 and 1550. In the following chapter, the scene shifts to Europe and the religious, dynastic, and national divisions that brought an end to a unified European Christendom and led to trade and imperial competition among the Atlantic-facing nation-states.

The fifth chapter shifts the focus once again, this time to labour migrations between 1500 and 1800 that led to the creation of full-fledged colonial societies in the Americas. Continuing the theme of labour migrations, the next chapter focuses on the transatlantic slave trade that provided the captive men and women who powered the Atlantic basin's plantation complexes while the following chapter discusses the Atlantic trade networks that formed to transport mineral and agricultural goods eastward and finished goods westward. A chapter on métissage and the mestizo societies that the Atlantic connections created concludes the first, social history-oriented, half of the book.

Politics and imperial rivalries drive the second half of the book, beginning with two chapters on the trade and territorial wars of the first three-quarters of the eighteenth century and the resulting American Revolution. The following two chapters recount the impact of the French and Haitian Revolutions on a crumbling imperial world, a weakening of European power that resulted in the creation of independence movements throughout Latin America, topics that are dealt with in the next chapter. The book concludes with a brief assessment of the rise of economic imperialism between 1780 and 1850 and the abolition of the slave trade between 1780 and 1888 .

Viewed from the perspective of a textbook, The Atlantic World does a fine job of introducing students to the main themes of Atlantic history. The writing is lively and accessible and the text will easily draw student readers into the multifaceted world created in the early modern Atlantic. I began teaching Atlantic history in the mid-1990s and would have been very grateful to have had this text at hand. That said, while an excellent overview of Atlantic history, The Atlantic World also reveals the limits of the concept it describes.

The vision of an Atlantic world that drives this, and many other related books, has made a signal contribution to scholarship over the past twenty years, but that long period of ascendancy has also allowed Atlantic history to reveal its limitations. As Peter Colanis noted in 2006, the Atlantic world leaks around its edges. The Atlantic Ocean was never self-contained and was part of a connected global system that joined the Atlantic to the Indian and Pacific (not to mention the Arctic and Antarctic) oceans. In the very same years that Atlantic Europe was exploring, plundering, and colonising the American continents and drawing millions of slaves from western Africa, these same nations were actively exploring, trading, and colonising in these other venues. At least two English voyages designed to both interdict the annual Spanish silver shipment from Peru to Panama and to create a settlement in southern Chile originated in the English Chesapeake and New England. Similar ventures by Holland and France departed from Atlantic Europe. Or consider that each of the leaders of the mid-eighteenth-century imperial voyages to Tahiti and the wider Pacific-Wallace, Cook, and Bougainville - called the Pacific Islanders "Indians" and treated them according to their, generally positive experiences with the native people of North America. Bougainville was even adopted into an Iroquois village. Further west, the smoking craze that swept through Late Ming and early Qing China was fueled in large part by Virginia tobacco. And, as Alison 
Games, one of the book's authors, has recently shown, the careers of European traders, diplomats, and administrators naturally drew them into and out of the Atlantic world, not only into the eastern Mediterranean, but into South and Southeast Asia and the Pacific as well. The list continues, but the point is that the Atlantic basin was only part of a wider world in which the Americas as well as Africa and Europe played a part.

While I think The Atlantic World would make the perfect textbook for an Atlantic history course, I no longer teach such a course. Instead my Atlantic history course has gradually transformed itself into a course about America in an early modern world. Atlantic history only tells part of that story.

doi:10.1017/S0165115312000277

Ronald Schultz, University of Wyoming

McGarrity, Maria. Washed by the Gulf Stream: The Historic and Geographic Relation of Irish and Caribbean Literature. Newark: University of Delaware Press, 2008. 196 pp., 1 photograph. ISBN: 9780874130287 (hbk.). \$40.00.

Washed by the Gulf Stream has the ambitious aim of exploring the history of Ireland in the Caribbean and excavating aesthetic overlaps in writing from the two regions that reveal a shared conceptual frame. In line with her twin objectives, the argument McGarrity advances is two-pronged: first she asserts that the Irish have had a greater influence upon and presence within the Caribbean than has hitherto been acknowledged, and second she argues that Irish and Caribbean writers have an analogous way of seeing that is a result of their island cultures. This two-part argument has a one-third, two-thirds split in the text; that is, the section on shared history occupies one of its four main chapters, and the section on aesthetic overlap takes up the subsequent three. While Washed by the Gulf Stream offers interesting insight along both lines of its branched thesis, and clears a wide path into this area of study, the book is weakened by its split structure and slight size. There is much of merit in this short text, but most of it demands more support, increased nuance and deeper integration.

What the book as a whole lacks is a single sustained and supported central argument, a discouraging fault that stems directly from its architecture. McGarrity asserts an underpinning theory in her introduction to the book, the idea that colonised island cultures have shared central characteristics which, in the case of Ireland and the Caribbean, result in an "island imaginary, that marks a foundation of identity and culture, which then serves as a force of mutual illumination for both literary traditions" (22). While this statement offers the promise of a thorough textual/contextual —and potentially even ecological/geographicalreading of the two traditions, it is a promise that is never fulfilled. Washed by the Gulf Stream is schematic - its chapters largely cordoned off from each other-and, as a consequence, the concept of an "island imaginary" is less a central thread that binds the sections together and more a similar stitch in the middle of four stand alone pieces.

The first taste of the nature of the text's composition is found in the first chapter, "Altering the 'Age of Silence': Historical Contexts for the Study of Irish and Caribbean Literature." The chapter begins shortly after McGarrity's introduction declares that "when the view of the colonised is privileged, it is evident that their imagined island geographies are not arbitrary spatial markers but become essential features of cultural belonging" (28). This statement, in the penultimate paragraph of the introduction, seems to set the scene and forecast that all that follows will involve an analysis of geography's influence on literary representation. The first chapter, then, comes as a shock; rather than picking up from the introduction, it dips into the origins of the Irish presence in the Caribbean by presenting a brief survey of early Irish outposts and Irish movement through the region. The chapter covers the Irish in the Amazon Basin, the large Irish community in Montserrat and the Irish in Barbados, Trinidad, and Jamaica. While it usefully complicates assumptions about Irish privilege as whites in a colonial society, and displays the ways in which the Irish, like other transported peoples in the 